\title{
Flora of some of the satellite islets of Sicily, Pantelleria, Lampedusa and Ustica (Italy)
}

\author{
Arnold Sciberras' \& Jeffrey Sciberras ${ }^{2}$ \\ ${ }^{1}$ 136, Animal Kingdom LTD. Ditch Street Paola, Malta PLA 1234; email: bioislets@gmail.com \\ 224, Camilleri Court, Flt 5, Il-Marlozz Street, Mellieha, Malta MLH 4100; email: wildalienplanet@gmail.com
}

\begin{abstract}
During the last decade, the authors visited several stacks (Faraglione) which are satellites islets around the main circum-sicilian islands. Most of these stacks are inaccessible to the general public due to their geographical and topographical positions/inclinations. Literature is often scarce or non-existent. The current work provides a preliminary data on the floral diversity recorded during the brief expeditions between the years 2008-2018. All of these islets were observed once, so this study does not reflect all of the possibly existing species of these islets. The current study caters the Faraglione di Colombara of Ustica, Isola dei Conigli, Scoglio del Sacramento and Scoglio di Faraglione of Lampedusa, Faraglione di Tracino and Faraglione di Ficaria/indietro l'isola of Pantelleria. Another islet is the Scoglio dello Zio Gennaro, Taormina, Sicily.
\end{abstract}

KEY WORDS Vegetation; satellites islets; circum-sicilian islands.

Received 16.10.2020; accepted 28.12.2020; published online 15.02.2021

\section{INTRODUCTION}

Satellite islets offer a unique opportunities in order to record new sites for species outside their normal range, as well possible new species or subspecies/populations to science. Moreover, they hold valuable untouched ecosystems which could have existed on the main islands nearby, but might have been greatly altered due to disturbance by human intervention. In shorter terms, they can be relic ecosystems. At the same time the micro-habitat of the latter offer to the biodiversity of the site to modify itself according to the harsh conditions provided, usually resulting in the only species endemic in the situ. Through such studies these islets can attain more levels of protection as their ecological importance would be noticed.

All of the islets have been physically visited.
The chances of accessing these islets and stacks proved crucial, as their flora has been thoroughly observed. Flat islets were easy to climb and to walk around their perimeters, but the stacks were mostly difficult, as most parts of the stack are vertical. Unfortunately some part of the stacks proved to be inaccessible. Further observations of such stacks, and even the flat islets, were also done telescopically, from the shores and cliffs of their main islands, respectively. The camera was the biggest tool at hand in-situ, and each different species observed was photographed.

Identification of the species was done both insitu and ex-situ.

Table 1 has the list of all species observed and is similar to one of our previous works (Sciberras \& Sciberras, 2010, 2012; Sciberras et al., 2012a, b). 


\section{RESULTS}

\section{ISLETS OF LAMPEDUSA}

\section{Scoglio del Sacramento (A)}

$31^{\circ} 31^{\prime} 43^{\prime \prime} \mathrm{N}-12^{\circ} 31^{\prime} 41^{\prime \prime} \mathrm{E}$, Observed in May 2010

Located along the north-western cliff of Lampedusa, roughly $25 \mathrm{~m}$ away from the cliff, this $40-50 \mathrm{~m}$ high stack is roughly $47-50 \mathrm{~m}$ long from north to south and $30 \mathrm{~m}$ wide from east to west. It is very sheer, almost entirely vertical on the west side, with a small slope on the east side where all of the vegetation occurs, however it is still sheer. The vegetation seems very monoculturous and occurs from the top of the stack until near the coast estimating roughly 5 to 3 meters above sea level. Most likely only two species occur there, Anthrocnemum macrostachyum and Limonium lapodusanum, as observed from afar.

\section{Scoglio di Faraglione (B)}

$31^{\circ} 31^{\prime} 44^{\prime \prime} \mathrm{N}-12^{\circ} 32^{\prime} 39^{\prime \prime} \mathrm{E}$, Observed in May 2010

Located along the northern cliffs of Lampedusa, some $20 \mathrm{~m}$ away from the cliff, this $10 \mathrm{~m}$ high stack is roughly $40 \mathrm{~m}$ long from north to south and $20 \mathrm{~m}$ wide from east to west, is smaller than Scoglio del Sacramento, but suprisingly has more species on it than the other, such as Daucus gingidium, Anthrocnenum macrostachysum, Rumex bucephalarus and possibly Limonium lopadusanum. However vegetation seems more sparse here and only occurs on the very top of the stack.

\section{Isola dei Conigli (C)}

$31^{\circ} 30^{\prime} 36^{\prime \prime} \mathrm{N}-12^{\circ} 33^{\prime 2} 29^{\prime \prime} \mathrm{E}$, Observed in May 2010

Located on the south side of the main island, 50 $m$ away, very close to Spiaggia dei Conigli, this islet is the fourth largest island of the archipelago, after Lampione. It is roughly $267 \mathrm{~m}$ long east to west, $128 \mathrm{~m}$ wide from north to south, highest point on the islet is $12 \mathrm{~m}$. Small cliffs surround most of the perimeter of the islet. The islet is temporarily connected to Lampedusa through a sandbar, especially during low tide in summer, making it a sandbar island, the only example in the archipelago. The islet is home to Psammodromus algirus, which occurs only on this islet in the entire archipelago.
The islet has the most varied floral community of those that surround Lampedusa, which is dominated by large shrubby species such as Pistacia lentiscus, Periploca angustifolia, Atriplex halimus and Salsoda oppostifolia. These large shrubby species cover the island almost entirely, leaving little room to other species. In fact the rest of the herbaceous species seem to be annual or perennial, only to grow in the exposed spaces. The only other shrub which grows only along the perimeter of the islet is Limonium lapodusanum.

\section{ISLETS OF PANTELLERIA}

\section{Faraglione di Tracino (D)}

$36^{\circ} 47^{\prime} 56^{\prime \prime} \mathrm{N}-12^{\circ} 03^{\prime} 07^{\prime}$ 'E, Observed in May 2018

Located in the north-eastern coast of the main island, near a peninsula of Tracino, some $27 \mathrm{~m}$ offshore, the islet is $68 \mathrm{~m}$ long from north to south while $40 \mathrm{~m}$ wide from east to west. Most probably it is $20 \mathrm{~m}$ high above sea-level, the highest point is closest to the shore, and it gently inclines downwards towards the north-east. The flora of the island is highly varied, but practically almost identical to the garigue of the nearby coast. Most common species seem to be Matthiola incana subsp.pulchella, Helichrysum rupestre var. errarae, Limonium cossyrense, and Malva dendromorpha. The last species seemed almost absent from the nearby coast. Malva dendromorpha is a typical species to coasts and islets.

\section{Faraglione indietro l'isola-Faraglione di Fi- caria (E) \\ $36^{\circ} 45^{\prime} 25^{\prime \prime} \mathrm{N}-12^{\circ} 03^{\prime} 10^{\prime \prime} \mathrm{E}$, Observed in May 2018}

The largest of the offshore stacks around Pantelleria, is roughly $68 \mathrm{~m}$ far from the coastal cliffs, is $46 \mathrm{~m}$ wide from east to west and $54 \mathrm{~m}$ long from south to north. Its highest point must be between $60 \mathrm{~m}$ to $70 \mathrm{~m}$. It has a conical shape with striking geomorphological large cuboid slabs protuding out in every upward direction which cover most of the surface of the stack, creating several shelthered crevices and patches with flat surfaces for ruprestal species to thrive. The stack is steep in every direction. The islet is well known for a large cluster of Opuntia ficus-indica on a top part of the stack facing south, hence the name. A mix 


\begin{tabular}{|c|c|c|c|c|c|c|c|}
\hline \multirow[t]{2}{*}{ Main island } & \multicolumn{3}{|c|}{ Lampedusa } & \multicolumn{2}{|c|}{ Pantelleria } & \multirow{2}{*}{$\begin{array}{c}\text { Ustica } \\
\text { F }\end{array}$} & \multirow{2}{*}{$\frac{\text { Sicily }}{G}$} \\
\hline & $\mathbf{A}$ & B & $\mathbf{C}$ & D & $\mathbf{E}$ & & \\
\hline \multicolumn{8}{|l|}{ Species } \\
\hline Anthemis sp. & & & & & & $\mathrm{X}$ & \\
\hline Antrocnenum macrostachyium (Moric.) C, Koch & $\mathrm{X}$ & $\mathrm{X}$ & & & & & \\
\hline Allium sp. & & & & $\mathrm{X}$ & & & \\
\hline Asparagus albus $\mathrm{L}$. & & & & & $\mathrm{X}$ & & \\
\hline Asparagus aphyllus $\mathrm{L}$. & & & $\mathrm{X}$ & & & & \\
\hline Atriplex halimus L. & & & $\mathrm{X}$ & & & & \\
\hline Avena sp. & & & & $\mathrm{X}$ & & & \\
\hline Brassica insularis Moris & & & & $\mathrm{X}$ & & & \\
\hline Capparis orientalis Veillard & & & $\mathrm{X}$ & $\mathrm{X}$ & $\mathrm{X}$ & & \\
\hline Carduus sp. & & & & & & $\mathrm{X}$ & \\
\hline Chenopodium sp. & & & $\mathrm{X}$ & & & & \\
\hline Critmum maritimum L. & & & & & & $\mathrm{X}$ & \\
\hline $\begin{array}{l}\text { Daucus carota subsp. depranensis (Archang.) } \\
\text { Henwood }\end{array}$ & $\mathrm{X}$ & $\mathrm{X}$ & & $\mathrm{X}$ & $\mathrm{X}$ & & \\
\hline Echium parviflorum Monech & & & $\mathrm{X}$ & & & & \\
\hline Euphorbia dendroides L. & & & & $\mathrm{X}$ & & & \\
\hline Euphorbia pinea L. & & & & $\mathrm{X}$ & $\mathrm{X}$ & & \\
\hline Ficus carica $\mathrm{L}$. & & & & $\mathrm{X}$ & & & \\
\hline Malva arborea (L.) Webb \& Berthel & & & & & $\mathrm{X}$ & & \\
\hline Mesembrythenum nodiflorum L. & & $\mathrm{X}$ & $\mathrm{X}$ & & & & \\
\hline $\begin{array}{l}\text { Matthiola incana subsp. pulchella (Conti) } \\
\text { Greuter \& Burdet }\end{array}$ & & & & $\mathrm{X}$ & $\mathrm{X}$ & & \\
\hline Misopates $\mathrm{sp}$. & & & & $\mathrm{X}$ & & & \\
\hline Leontodon sp. & & & & $\mathrm{X}$ & & & \\
\hline Limbadia crithmoides (L.) Dumort & & & & & & & $\mathrm{X}$ \\
\hline Limonium cossyrense (Guss.) Kuntze & & & & $\mathrm{X}$ & $\mathrm{X}$ & & \\
\hline Limonium lopadusanum Brullo & $\mathrm{X}$ & $\mathrm{X}$ & $\mathrm{X}$ & & & & \\
\hline Lobularia maritima (L.) Devs & & & $\mathrm{X}$ & & & & \\
\hline Helichrysum rupestre var. errarae (Tin.) Pign. & & & & $\mathrm{X}$ & $\mathrm{X}$ & & \\
\hline Hyoscomus albus $\mathrm{L}$. & & & & $\mathrm{X}$ & & & \\
\hline Ononis natrix subsp. ramossisma (Desf.) Batt. & $\mathrm{X}$ & $\mathrm{X}$ & $\mathrm{X}$ & & & & \\
\hline Olea europeae subsp. sylvestris (Miller) Lehr & & & & $\mathrm{X}$ & & & \\
\hline Opuntia ficus-indica (L.) Mill. & & & & $\mathrm{X}$ & & & \\
\hline Orobanche cernua Loefl. & & & $\mathrm{X}$ & $\mathrm{X}$ & & & \\
\hline Parietaria cretica L. & & & & $\mathrm{X}$ & $\mathrm{X}$ & & \\
\hline Periploca angustifolia Labill. & & & $\mathrm{X}$ & $\mathrm{X}$ & & & \\
\hline Pharalis sp. & & & & $\mathrm{X}$ & & & \\
\hline Pistacia lentiscus L. & & & $\mathrm{X}$ & & $\mathrm{X}$ & & \\
\hline Reseda alba L. & $\mathrm{X}$ & & & $\mathrm{X}$ & & & \\
\hline Roccella sp. & & & & & $\mathrm{X}$ & & \\
\hline Rubia peregrina $\mathrm{L}$. & $\mathrm{X}$ & $\mathrm{X}$ & $\mathrm{X}$ & $\mathrm{X}$ & & & \\
\hline \multicolumn{8}{|l|}{ Rumex bucephalarus $\mathrm{L}$. } \\
\hline Sonchus olearaceus L. & & & & $\mathrm{X}$ & $\mathrm{X}$ & & \\
\hline Salsoda oppostifolia Desf. & & & $\mathrm{X}$ & & & & \\
\hline Sedum album L. & & & & $\mathrm{X}$ & & & \\
\hline Senecio leuncanthifolius Poir. & & & $\mathrm{X}$ & & & & \\
\hline Thapsia garganica L. & & & $\mathrm{X}$ & & & & \\
\hline Umbilicis sp. & & & & $\mathrm{X}$ & & & \\
\hline Valantia muralis $\mathrm{L}$. & & & & & $\mathrm{X}$ & & \\
\hline
\end{tabular}

Table 1. Flora of some of the satellite islets of Sicily, Pantelleria, Lampedusa and Ustica. 
of rupestral and ruderal species occur. The highest part is dominated by Periploca angustifolia. Other species that occur here are common around in entire island of Pantelleria, such as those mentioned in Faraglione di Trachino, except for one species, Brassica insularis, which seemed dominant on the islet, especially on the north side, but absent on nearby cliffs of the main island. However, this species has been recorded from five stations around Pantelleria, but not on the islet, where the majority of the population resides.

\section{ISLET OF USTICA}

\section{Faraglione - Scoglio di Colombara (F)}

$38^{\circ} 43^{\prime} 11^{\prime \prime} \mathrm{N}-13^{\circ} 10^{\prime} 58^{\prime \prime} \mathrm{E}$, Observed in October 2011

Situated in the north of the island of Ustica, 36 $\mathrm{m}$ offshore. It is $25 \mathrm{~m}$ long north to south, same east to west, with a probable height of 15 to $18 \mathrm{~m}$ above sealevel, so it has a cuboid shape overall. It has a flat plateau, slightly dome-like. Very few species occur on the plateau, mainly Crithmum maritimum as the dominant perennial.

\section{ISLET OF SICILY (TAORMINA)}

\section{Scoglio dello Zio Gennaro (G)}

$37^{\circ} 51^{\prime} 34^{\prime \prime} \mathrm{N}-15^{\circ} 18^{\prime} 07^{\prime \prime} \mathrm{E}$, Observed in October 2011

This islet is situated near the city of Taormina, close to the bay of Isola Bella. It is $112 \mathrm{~m}$ away from the shore, $47 \mathrm{~m}$ from north to south and $27 \mathrm{~m}$ from east to west. The islet is $10 \mathrm{~m}$ high at sea level. The sea around the islet seems very deep, since that part of Sicily has a very deep coast. The only species to reside on the islet is Limbarda crithmoides, which is very adapted for halophytic environs, however the size of the islet can support more species, but, unexplainably, this is not the case.

\section{DISCUSSION AND CONCLUSIONS}

Apart from wind, birds must play an important role in carrying seeds to these islets, and have a profound effect to the density and richness of other fauna species (see Cilia et al., 2012). The authors have observed a few gull species such as Laurus argentatus Pontoppidan, 1763 Spanish Sparrows, Passer hispaniolensis (Temminck, 1820), and the Blue Rock Thrush, Monticola solitaris solitaris (Linnaeus, 1758). Field cockroach, Loboptera decipiens (Germar, 1817), was observed on Faraglione di Ficaria, while an unidentified species of cricket and silverfish where observed on Faraglione di Colombaro of Ustica. Living specimens of Ectobius sp., and evidence of sounds of a colony of Tadarida teniotis (Rafinesque, 1814), including skull and wing fragments, were found in Scoglio dello Zio Gennaro. Individuals of Podarcis sp. were observed on Faraglione di Ficaria and Scoglio di Faraglione. Regarding Lepidoptera, during the visit to Faraglione di Ficaria, a fair amount of Pieris brassicae (Linnaeus, 1758) and one Vanessa atalanta (Linnaeus, 1758). At Isola dei Conigli Colias croceus (Geoffroy, 1785) and three Papilon machaon Linnaeus, 1758 have been observed. Two Vanessa atalanta and three Pieris rapae (Linnaeus, 1758) were observed on Scoglio dello Zio Gennaro. Another two Pieris rapae were also found on Scoglio di Colombara.

\section{REFERENCES}

Cilia D.P., Sciberras A., Sciberras J. \& Pisani L., 2012. Terrestrial gastropods of the minor islets of the Maltese Archipelago. (Mollusca Gastropoda) Biodiversity Journal, 3: 543-554.

Sciberras A. \& Sciberras J., 2010. Topography and Flora of the Satellite islets surrounding the Maltese Archipelago. The Central Mediterranean Naturalist 5: 31-42. Nature Trust Malta publications.

Sciberras A. \& Sciberras J., 2012. Flora of "U Briantinu", a satellite stack of Panarea Island, Aeolian Archipelago (Sicily, Italy) Biodiversity Journal, 3: 397-399.

Sciberras A., Sciberras J. \& Pisani L., 2012. Updated Checklist of Flora of the Satellite islets surrounding the Maltese Archipelago. Biodiversity Journal, 3: 385-396.

Sciberras A., Sciberras J., Sammut M. \& Aloise G., 2012. A contribution to the knowledge of the terrestrial Mammalian fauna of Comino and its satellite islets. (Maltese archipelago). Biodiversity Journal, 3: 191200. 